NBER WORKING PAPER SERIES

\title{
LABOR MARKET CONCENTRATION
}

\author{
José Azar \\ Ioana Marinescu \\ Marshall I. Steinbaum \\ Working Paper 24147 \\ http://www.nber.org/papers/w24147
NATIONAL BUREAU OF ECONOMIC RESEARCH
1050 Massachusetts Avenue
Cambridge, MA 02138 \\ December 2017, Revised February 2019
}

José Azar gratefully acknowledges the financial support of Secretaria d'Universitats I Recerca del Departament d'Empresa I Coneixement de la Generalitat de Catalunya. Ref.2016 BP00358. Marshall Steinbaum gratefully acknowledges the financial support of the Ewing Marion Kauffman Foundation. We thank Jonathan Baker, Einer Elhauge, Hiba Hafiz, Larry Katz, Alan Krueger and Michael Ransom for helpful comments. The views expressed herein are those of the authors and do not necessarily reflect the views of the National Bureau of Economic Research.

At least one co-author has disclosed a financial relationship of potential relevance for this research. Further information is available online at http://www.nber.org/papers/w24147.ack

NBER working papers are circulated for discussion and comment purposes. They have not been peer-reviewed or been subject to the review by the NBER Board of Directors that accompanies official NBER publications.

(C) 2017 by José Azar, Ioana Marinescu, and Marshall I. Steinbaum. All rights reserved. Short sections of text, not to exceed two paragraphs, may be quoted without explicit permission provided that full credit, including $\odot$ notice, is given to the source. 
Labor Market Concentration

José Azar, Ioana Marinescu, and Marshall I. Steinbaum

NBER Working Paper No. 24147

December 2017, Revised February 2019

JEL No. J2,J3,L1,L4

\section{$\underline{\text { ABSTRACT }}$}

A product market is concentrated when a few firms dominate the market. Similarly, a labor market is concentrated when a few firms dominate hiring in the market. Using data from the leading employment website CareerBuilder.com, we calculate labor market concentration for over 8,000 geographic-occupational labor markets in the US. Based on the DOJ-FTC horizontal merger guidelines, the average market is highly concentrated. Using a panel IV regression, we show that going from the 25 th percentile to the 75 th percentile in concentration is associated with a $17 \%$ decline in posted wages, suggesting that concentration increases labor market power.

José Azar

IESE Business School, Universidad de Navarra

Avinguda Perason 21

08034 Barcelona, Spain

jazar@iese.edu

Ioana Marinescu

University of Pennsylvania

School of Social Policy \& Practice

3701 Locust Walk

Philadelphia PA, 19104-6214

and NBER

ioma@upenn.edu
Marshall I. Steinbaum

Roosevelt Institute, 1789 Lanier Pl, NW Apt 1

Washington, DC 20009

msteinbaum@gmail.com 


\section{Introduction}

There is growing concern about increasing market concentration and its potential effects on the economy, including increases in markups (De Loecker and Eeckhout, 2017) and the decline in the labor share (Autor et al., 2017; Barkai, 2016). Concerns about a lack of competition in the labor market have also reached the policy debate (CEA, 2016). While interest in monopsony has grown in recent years (Ashenfelter, Farber and Ransom, 2010; Manning, 2011), firms' ability to pay workers less than their marginal productivity is not generally taken into account in antitrust practice. Antitrust enforcement is mainly concerned with consumer welfare, and hence the impacts of a lack of competition on product prices, not wages. Antitrust enforcers have historically paid little attention to labor market power, despite the labor economics literature finding that firms can have substantial market power in the labor market (Staiger, Spetz and Phibbs, 2010; Falch, 2010; Ransom and Sims, 2010; Matsudaira, 2013). This empirical work has generally focused on particular labor markets. Therefore it is not clear how widespread labor market power truly is, and how much it affects wages.

In this paper, we approach this question by directly quantifying the level of labor market concentration across a wide range of occupations and for almost every commuting zone in the US. In a nutshell, we find that labor market concentration in the average market is high, and higher concentration is associated with significantly lower posted wages. Given high concentration, mergers have the potential to significantly increase labor market power. This type of analysis could be used by antitrust agencies to assess whether mergers can create anti-competitive effects in labor markets.

We measure labor market concentration using traditional measures such as the HerfindahlHirschman Index (HHI), which have the advantage that they can be compared with the thresholds in the antitrust agencies' horizontal merger guidelines (FTC/DOJ, 2010). The same thresh-

olds apply to seller and buyer power, as the horizontal merger guidelines state that "To evaluate whether a merger is likely to enhance market power on the buying side of the market, the 
Agencies employ essentially the framework described above for evaluating whether a merger is likely to enhance market power on the selling side of the market." The buying side of the market refers to inputs markets, including the labor market. Therefore, a merger can be said to enhance market power if it results in a high level of concentration in specific labor markets.

To calculate market shares in geographic and occupational labor markets, we use data from CareerBuilder.com, the largest online job board in the United States, matching millions of workers and firms. We calculate vacancy shares and HHIs of market concentration for over 8,000 labor markets, defined by a combination of occupation at the SOC-6 level and commuting zone. The occupations we cover include the most frequent occupations among CareerBuilder vacancies, plus the top occupations in manufacturing and construction. We show that, on average, labor markets are highly concentrated: the average $\mathrm{HHI}$ is 3,157, which is above the 2,500 threshold for high concentration according to the Department of Justice / Federal Trade Commission horizontal merger guidelines. Concentration varies by occupation and city, with larger cities being less concentrated.

We document a negative correlation between labor market concentration and average posted wages in that market. We then run both OLS and instrumental variables (IV) regressions of posted wages on concentration at the market level (HHI), using quarterly panel data ranging from 2010 to 2013. Our instrument for the IV specification is the inverse number of posting employers in other geographic markets for the same occupation in a given quarter. This instrument uses variation in market concentration that is driven by national-level changes in occupational hiring over time, and not by potentially endogenous changes in occupational hiring within a particular local market.

The OLS and IV results are qualitatively similar, but quantitatively the instrumented estimates are much larger. In the baseline IV specification, the elasticity of the real wage with respect to the $\mathrm{HHI}$ is -0.127 , while in the baseline OLS specification the elasticity is -0.038 . Going from the 25 th to the 75 th level of concentration decreases posted wages by $17 \%$ in the baseline IV specification, and by $5 \%$ in the baseline OLS specifications. The instrument we use may not 
be fully exogenous. Therefore, we allow departures from full exogeneity (Conley, Hansen and Rossi, 2010): we find that the second-stage estimate of the impact of $\mathrm{HHI}$ on wages is bounded away from zero as long as the direct (endogenous) effect of the instrument on wages is not more than $75 \%$ of the reduced form effect. We thus show that the negative effect of $\mathrm{HHI}$ on wages is robust even for large departures from exogeneity.

One might be concerned that the impact of concentration on posted wages is endogeneous due to the relationship between the number of vacancies and concentration. The sign of the bias could be positive or negative: a decrease in labor demand can lower wages and the number of firms hiring in the market, leading to higher concentration; a decrease in labor supply can increase wages, and lower the number of firms hiring, also leading to higher concentration. To alleviate this concern, we control for labor market tightness, defined as vacancies/applications (Davis and Marinescu, 2017). We find that the negative effect of concentration on wages is essentially unchanged. Overall, our results are consistent with labor market concentration creating labor market power, and hence putting downward pressure on wages.

We perform a number of additional robustness checks. Most importantly, Marinescu and Wolthoff (2016) show that posted wages are largely explained by job titles. Therefore, it is important to control for heterogeneity by job title to get an estimate of the impact of concentration on wages for a given job type. When we control for job titles, the effect of concentration on wages is still highly significant and negative but smaller, suggesting that concentration may change the composition of jobs toward lower paying jobs. We also use alternative measures of labor market concentration, such as the inverse of the number of hiring firms, or market concentration as measured by the number of applications: these alternative measures also yield a negative and highly significant impact of labor market concentration on posted wages.

This paper provides for the first time to our knowledge a measure of labor market concentration for many of the largest labor markets in the US. Our measure of concentration is distinct from the industry concentration measures used by Autor et al. (2017) and Barkai (2016): it is 
based on concentration in the labor market rather than concentration in the product market. ${ }^{1}$ Our contribution is therefore complementary: while those authors show that product market concentration is associated with a lower labor share, we show that labor market concentration is associated with lower posted wages.

The papers that come closest to ours in approach are Benmelech, Bergman and Kim (2018) and Rinz (2018), which build on the present article by studying concentration of employment in labor markets defined by geography and industry, using Census data on employment by firms and establishments.

The monopsony literature in labor economics approaches the issue of market power through questions such as the impact of the minimum wage and unionization. This literature focuses on the elasticity of labor supply to the individual firm, as opposed to market concentration ${ }^{2}$. In such "New Monopsony" models, employers trade off wages with their employees' quit rates, and they face an upward-sloping supply curve due to search frictions, firm-specific amenities, and limited geographic mobility of workers, in addition to other mechanisms. If workers have a high labor supply elasticity, then firms pay them more to get them to stay. The literature generally finds low elasticities of labor supply and interprets this as evidence for firm-level monopsony power to reduce wages below the marginal product of labor (Webber, 2015; Dube et al., 2019).

Our approach is complementary to this literature, but with a different mechanism at play. We measure market-level concentration in local and occupational labor markets, implicitly arising from restrictions to employer entry or other characteristics of firms or industries, as opposed to characteristics of workers. In our framework, firms pay higher wages if the labor market is unconcentrated and workers can expect abundant job offers from competing employers.

\footnotetext{
${ }^{1}$ To our knowledge, the last published measurement of labor market concentration is Bunting (1962). Boal and Ransom (1997) reviewed the literature.

${ }^{2}$ An older literature has explored the impact of labor market concentration on wages. However, this literature is mostly limited to teachers' and nurses' markets and uses cross-sectional identification, as discussed in Boal and Ransom (1997).
} 
Buyer-side market power caused by concentration and the upward-sloping firm-level labor supply curve are mutually-reinforcing mechanisms for monopsony power and for the empirical findings from the aforementioned labor literature, such as the small effect of minimum wage increases on employment.

The remainder of the paper is organized as follows. Section 2 describes the data, and our measure of labor market concentration. Section 3 analyzes the relationship between labor market concentration and posted wages. Section 4 performs robustness tests and addresses remaining limitations. Finally, section 5 concludes.

\section{Measuring labor market concentration}

\subsection{Data}

We use proprietary data from CareerBuilder, which is the largest online job board in the United States. The site received approximately 11 million unique job seeker visits in January 2011. Job seekers can use the site for free, while firms seeking to hire workers must pay a fee of several hundred dollars to post a job opening for one month. The total number of vacancies on CareerBuilder.com represents 35\% of the total number of vacancies in the US in January 2011 as counted in the Job Openings and Labor Turnover Survey. The dataset used here was first used in Davis and Marinescu (2017). Occupations were selected based on counts of jobs posted between 2009 and 2012 on CareerBuilder: at the broad SOC level, i.e. SOC-5 digits, the 13 most frequent occupations were selected. We also added the three most frequent occupations in manufacturing and construction (17-2110, 47-1010, 51-1010). The full list of SOC-6 occupations is as follows:

- 11-3011 Administrative services managers

-13-2011 Accountants and Auditors 
- 13-2051 Financial Analysts

- 13-2052 Personal financial advisers

- 13-2053 Insurance Underwriters

- 13-2061 Financial Examiners

- 15-1041 Computer support specialists

- 17-2111 Health and Safety Engineers, Except Mining Safety Engineers and Inspectors

- 17-2112 Industrial engineers

- 29-1111 Registered nurses

- 41-4011 Sales representatives, wholesale \& manufacturing, technical \& scientific products

- 41-9041 Telemarketers

- 43-3031 Bookkeeping, accounting, and auditing clerks

- 43-4051 Customer service representatives

- 43-6011 Executive secretaries and administrative assistants

- 43-6012 Legal Secretaries

- 43-6013 Medical secretaries

- 43-6014 Secretaries and Administrative Assistants, Except Legal, Medical, and Executive

- 47-1011 First-Line Supervisors of Construction Trades and Extraction Workers

- 49-3041 Farm equipment mechanics

- 49-3042 Mobile Heavy Equipment Mechanics, Except Engines 
- 49-3043 Rail Car Repairers

- 51-1011 First-line supervisors/managers of production and operating workers

- 53-3031 Driver/sales workers

- 53-3032 Truck drivers, heavy and tractor-trailer

- 53-3033 Light Truck or Delivery Services Drivers

Our data includes, for each vacancy, the number of applicants. This allows us to calculate labor market tightness at the occupation by local labor market level as (number of vacancies)/(number of applications).

Only about $20 \%$ of the CareerBuilder vacancies post salary information. The posted wage is converted into an annual salary if it is hourly. The posted wage is defined as the middle of the range if the vacancy posts a range rather than a single value. We estimate posted wages for a given market and year-quarter as the simple average of the posted wage in the wage-posting vacancies. Figure 1 shows the distribution of log real wages across markets and year-quarters. The distribution is bi-modal and there are a small number of outliers on the left and the right sides of the distribution.

\subsection{Labor market definition}

Given that monopsony power in labor markets has not been a focus of antitrust policy, the crucial question of how to define the relevant market for antitrust analysis is relatively unexplored in the literature. The twin imperatives contained in the Horizontal Merger Guidelines are that markets be defined in terms of "lines of commerce" and "section of the country."

Marinescu and Rathelot (2018) show that applications to a job decline rapidly with distance, although most applications are still outside the applicant's zip code. It is therefore key to define labor markets geographically to obtain meaningful measures of market concentration. For our 
baseline analysis, we use commuting zones (CZs) to define geographic labor markets. Commuting zones are geographic area definitions based on clusters of counties that were developed by the United States Department of Agriculture (USDA) using data from the 2000 Census on commuting patterns across counties to capture local economies and local labor markets in a way that is more economically meaningful than county boundaries. According to the USDA documentation, "commuting zones were developed without regard to a minimum population threshold and are intended to be a spatial measure of the local labor market." Marinescu and Rathelot (2018) also show that $81 \%$ of applications on CareerBuilder.com are within the commuting zone, and Manning and Petrongolo (2017) similarly find that labor market searches are local in UK data, and Bartik (2018) finds evidence against full worker mobility across commuting zones. We conduct robustness checks using single counties for our geographic market definition instead of commuting zones.

When it comes to defining the analog to "line of commerce" in labor markets, the economic literature shows that there are substantial frictions associated with transitioning between jobs (Artuc, Chaudhuri and McLaren, 2010; Dix-Caneiro, 2014; Artuc and McLaren, 2015; Traiberman, 2017; Macaluso, 2017). No work, to our knowledge, attempts to define labor markets in the education space. Macaluso (2017) defines the concept of "skill remoteness" on the supply and demand sides of a labor market and finds that workers whose skills are further away from the available jobs in their local labor market (defined by city and occupation) are more likely to either move or exit the labor force in response to a layoff. Hershbein and Kahn (2016) and Modestino, Shoag and Ballance (2016) characterize the skill distribution of job vacancies as changing in response to the severity of local labor market recessions. But the extent to which workers confine their job searches to an education- or skills-delimited segment of available jobs has not yet been systematically explored (but see some evidence on search across occupations in Marinescu and Rathelot (2018)).

Using the a vacancies dataset from the same source as the one used in this paper, Marinescu and Wolthoff (2016) show that, within a 6-digit SOC, the elasticity of applications with respect 
to wages is negative. Therefore, the 6-digit SOC is likely too broad to be a labor market, since we would expect applications to increase in response to posted wages in a frictional labor market (see Subsection 3.3 below). Nonetheless, we consider SOC-6 occupation to be a conservative benchmark, with the understanding that concentration measured within labor markets defined that way is likely to be an under-estimate.

We calculate labor market concentration using posted vacancies and applications to those vacancies. Concentration could also be computed using observed employment (albeit not with this dataset). The concentration of employment is almost certainly lower than the concentration of vacancies-only a subset of the firms in a given labor market (defined by geography and occupation) will be hiring at any given time. But our measure of concentration based on vacancies is more relevant for active job seekers, especially in light of evidence of lengthening job tenures, which implies that a given position will remain filled for longer (Hyatt and Spletzer, 2016). Moreover, our results about the effect of concentration on wages are estimated from variation in concentration over time within a labor market, and in our robustness checks we aggregate vacancy postings over time, which reduces observed concentration levels-toward what we would probably observe if concentration were computed from firm-level employment.

We do our analysis at the quarterly level, since the median duration of unemployment was about 10 weeks in 2016 BLS (2017). We consider for our market share calculations all vacancies or applications that occur within a given quarter, including vacancies with missing wages.

\subsection{Measuring concentration}

We keep an unbalanced panel of 61,017 CZ-occupation-year-quarter observations, covering the period 2010Q1-2013Q4, 681 commuting zones, and 26 SOC 6-digit occupations. These markets all include at least one vacancy with a posted wage.

Our baseline measure of market power in a labor market is the Herfindahl-Hirschman Index (HHI) calculated based on the share of vacancies of all the firms that post vacancies in 
that market. ${ }^{3}$ The HHI is widely used as a measure of market concentration in the industrial organization literature and in antitrust practice. An advantage of this measure of market concentration is that there are guidelines for what represents a high level of market concentration. The DOJ/FTC guidelines: an HHI above 1500 is "moderately concentrated", and above 2500 is "highly concentrated". An HHI of 2,500 occurs when four employers have equal shares of the vacancies in a labor market. A merger that increases the HHI by more than 200 points, leading to a highly concentrated market is "presumed likely to increase market power".

While these measures and thresholds are generally used to evaluate market concentration in product markets, the antitrust agency guidelines state that " $t$ to evaluate whether a merger is likely to enhance market power on the buying side of the market, the Agencies employ essentially the framework describe above for evaluating whether a merger is likely to enhance market power on the selling side of the market." This implies that adverse effects of mergers on the inputs market, including the labor market, are part of the legal framework for evaluating mergers.

The formula for the HHI in market $m$ and year-quarter $t$ is

$$
\mathrm{HHI}_{m, t}=\sum_{j=1}^{J} s_{j, m, t}^{2}
$$

where $s_{j, m}$ is the market share of firm $j$ in market $m$. For the HHI based on vacancies, the market share of a firm in a given market and year-quarter is defined as the sum of vacancies posted in CareerBuilder by a given firm in a given market and year-quarter divided by total vacancies posted in the website in that market and year-quarter. We treat all vacancies posted by a recruiting / staffing firm as belonging to the same firm, since we cannot observe which firm the recruiting / staffing firm is hiring for.

In addition to calculating HHIs for each labor market based on shares of vacancies, we

\footnotetext{
${ }^{3}$ By confining this investigation to only the largest online job board, CareerBuilder, we add another dimension to market definition, that of the search platform. If workers search for jobs across multiple platforms, this might yield an excessive concentration estimate, but if most users use only one platform, then that concern would be mitigated.
} 
also calculated HHIs based on shares of applications (more specifically Expressions of Interest, i.e. clicking on the button "Apply now"). For the HHI based on applications, we define the market share of a firm in a given market and year-quarter as the sum of applications through the website to a given firm in a given market and year-quarter divided by the total number of applications to all firms in that market and year-quarter.

Table 1 shows summary statistics of the main variables used in our analysis. The average real wage was 41,547 USD (in 2009 dollars). The average market in our sample had 20 firms, 83 vacancies, 441,156 searches, and 3,612 applications. The average HHI based on vacancies was 3,157. The average HHI based on applications was somewhat higher: 3,480, reflecting the fact that not all vacancies received the same level of interest from job seekers.

Table 1 also shows that the average HHI calculated using shorter time periods than the quarter is higher, and the HHI using longer time periods is lower but still highly concentrated. The population-weighted quarterly $\mathrm{HHI}$ is lower and moderately concentrated. As would be expected, county-level HHIs are higher than CZ-level HHIs, and state-level HHIs are lower than CZ-level HHIs. With the exception of a state-level definition of the labor market, all alternative definitions still show moderate to high concentration.

Figure 2 shows a map of all the commuting zones in the United States color-coded by the average HHI, based on vacancy shares. Commuting zones around large cities tend to have lower levels of labor market concentration than smaller cities or rural areas. This suggests a new explanation for the city-wage premium (Yankow, 2006; Baum-Snow and Pavan, 2012): cities, and especially large cities, tend to have less concentrated labor markets than rural areas. ${ }^{4}$

Figure 3 shows the distribution of the HHIs based on vacancies and of the HHI based on applications in our sample. Under both definitions for market shares, the median market is moderately concentrated, while the average market is highly concentrated.

Figure 4 shows the average HHI, based on vacancy shares, by 6-digit SOC occupation. The occupations that are least concentrated on average are "Customer service representatives",

\footnotetext{
${ }^{4}$ Manning (2010) shows evidence on plant size that is consistent with lower monopsony power in cities.
} 
"Sales representatives, wholesale and manufacturing, technical and scientific products", and "Registered nurses", each with an average HHI of around 2,000. The occupations that are most concentrated on average are "Farm equipment mechanics", "Rail car repairers", and "Light truck or delivery services drivers", each with an average HHI well above 5,000 (which is the level of concentration of a symmetric duopsony market).

In summary, we find that reasonably defined local labor markets are highly concentrated on average. A limitation of our analysis is that we only use vacancies posted on the CareerBuilder website. ${ }^{5}$ Given that CareerBuilder is the largest job-posting website in the United States, the high level of concentration was somewhat surprising to us, especially given that many economists' prior seems to be that labor market monopsony power, if it exists at all, is due primarily to search frictions. Our findings can, however, be consistent with the search frictions story, in the sense that if we consider a longer time period the market is less concentrated (Table 1). Also, while the CareerBuilder website does not contain all vacancies, it is likely that, for job seekers who use it, the site is a main source of information on the labor market.

\section{Concentration and wages}

Figure 5 shows a binned scatter plot of the log real wage and log HHI based on vacancies. The two variables are strongly correlated and the association is close to log-linear. Appendix Figure 6 shows a similar relationship between the real wage and market concentration obtains when using the log HHI based on applications instead of the log HHI based on vacancies.

This negative correlation between market concentration and real wages is consistent with standard oligopsony theory, which predicts that firms in more concentrated labor markets should be able to pay workers wages below their marginal product. Of course, we cannot infer a causal relationship from this correlation alone. It could be driven, for example, by the fact that larger cities tend to have both a higher number of firms and higher wages, perhaps

\footnotetext{
${ }^{5}$ This is less of an issue for interpreting the within-market variation over time in concentration, which is the basis for the regression analysis in the following section.
} 
due to a higher cost of living. To address this issue, we conduct panel regressions that control for commuting zone by occupation effects, and identify the effect purely from variation in concentration and wages over time within a given commuting zone-occupation pair.

\subsection{Empirical specification: OLS and IV}

Our baseline specification is the following:

$$
\log \left(w_{m, t}\right)=\beta \cdot \log \mathrm{HHI}_{m, t}+\gamma \cdot X_{m, t}+\alpha_{t}+v_{m}+\varepsilon_{m, t}
$$

where $\log (w)$ is the $\log$ real wage in market $m$ in year-quarter $t, \log \mathrm{HHI}_{m, t}$ is the corresponding $\log$ HHI, $X_{m, t}$ is a set of controls, and $\alpha_{t}$ and $\delta_{m}$ are year-quarter and market (commuting zoneoccupation) fixed effects and $\epsilon_{m, t}$ is an error term.

We run a first specification with just year-quarter fixed effects. We then add successively market (CZ by SOC-6) fixed effects and log tightness (defined as the number of vacancies divided by the number of applications in a labor market) in the commuting zone and occupation for a given year-quarter. We then run a fourth specification further controlling for year-quarter by commuting zone, and finally we also add year-quarter by SOC fixed effects in a fifth specification, to control for any possible changes in the characteristics of the commuting zone or the occupation over time. We cluster standard errors at the commuting zone-occupation level.

The key threat to identification is that there is a time-varying market-specific variable that is correlated with HHI and drives wages. According to search and matching theory, posted wages are determined by labor market tightness, productivity and the worker's out-of-work benefit (Rogerson, Shimer and Wright, 2005). We already control for labor market tightness. Since unemployment benefits are determined at the state level, we are able to control for workers' out-of-work benefits by controlling for market fixed effects, and, in some specifications market by time fixed effects. Therefore, the main threat to identification is time-varying market-specific productivity changes. 
To further address the issue of the endogeneity of HHI, we instrument the HHI with the average of $\log (1 / N)$ in other commuting zones for the same occupation and time period (where $N$ refers to the number of firms in the market). That is, for each commuting zone-occupationtime period combination, we calculate the average of $\log (1 / N)$ for the same occupation for every other commuting zone. We use $\log (1 / N)$ instead of $H H I$ as the instrument because it is less likely to be endogenous, as it does not depend on market shares. This provides us with variation in market concentration that is driven by national-level changes in the occupation, and not by changes in the occupation in that particular local market. For example, if the productivity of customer service representatives falls in the Chicago area, this could both decrease wages and increase concentration, since fewer firms would likely be recruiting. By instrumenting with the number of firms posting vacancies for customer service representatives in other areas, we rule out a direct effect of productivity in Chicago on the HHI.

This type of instrumental variables strategy is commonly used in industrial organization to address the endogeneity of prices in a local product market. For example, Nevo (2001) uses prices in other geographic markets to instrument for city-level prices of various products in the ready-to-eat cereal industry. Outcomes in other geographic units have also been used as instruments in Autor, Dorn and Hanson (2013), who instrument for growth in US imports from China using Chinese imports in other high-income countries.

The main threat to identification for the instrumental variable strategy is that productivity shocks could be correlated across areas. For example, a national level decline in the productivity of customer service representatives would likely increase concentration and decrease wages in most labor markets. Therefore, the instrument protects us against a spurious correlation between concentration and outcomes that is due to local changes in productivity, but not against national-level changes in productivity (for an occupation relative to other occupations) that influence both concentration and other labor market outcomes.

While the instrument may not be not fully exogenous, it is plausibly more exogenous that the local market HHI, in particular because it is less likely to be correlated with uncontrolled 
for variations in productivity for the local CZ by occupation market. We exploit this idea by deriving bounds for the causal effect of HHI on wages using the method developed by Conley, Hansen and Rossi (2010). Suppose that the instrument has a direct effect on the outcome of interest, with a coefficient of $\gamma \neq 0$. If we assume a range of values for $\gamma$, we can derive an interval for the causal effect of the HHI on wages. The stronger the first stage, the tighter the interval for the causal effect.

\subsection{Regression results}

We find that higher labor market concentration is associated with significantly lower real wages. Table 3 Panel A shows the results from the baseline wage regressions. In the first regression, using vacancy-share HHIs and only year-quarter fixed effects, we find that a one log point increase in the $\mathrm{HHI}$ is associated with a decline in wages of about 0.103 log points. Further controlling for market fixed effects ( $\mathrm{CZ}$ by 6-digit SOC) reduces the coefficient to -.0347, showing that some of the negative relationship between posted wages and $\mathrm{HHI}$ is driven by cross-sectional variation in posted wages. Specification (3) shows that controlling for log tightness and does not substantially change the result from specification (2). We consider specification (3) to be the baseline for OLS results. Figure 7 shows a binned scatter corresponding to specification (3): the relationship between the residualized wages and the residualized HHI is negative and linear, similar to the raw relationship between wages and HHI (Figure 5).

Specifications 4 and 5 allow for commuting zone and occupation effects to change over time. Adding year-quarter by $\mathrm{CZ}$ fixed effects does not affect the impact of $\mathrm{HHI}$ on wages (compare column 3 and 4 in Table 3), showing that the effects are not driven by time-varying effects at the $\mathrm{CZ}$ level. When we further add year-quarter by 6-digit SOC fixed effects (column 5), the impact of $\mathrm{HHI}$ on wages remains negative and of a similar size. This shows that the negative impact of HHI on wages is not explained away by changes in occupational wages over time, due to e.g. technological change.

Specifications (6) to (8) show analogous results but based on the instrumental variables es- 
timation strategy (see Table 2 for the first stage). The estimated effect is still negative but much larger in absolute value. The IV estimate may be higher because it corrects the endogeneity bias from market-level labor supply and demand effects, and possibly also corrects for measurement error. A one log point increase in the $\mathrm{HHI}$ is associated with a decline in wages of about $0.14 \log$ points. This implies that an increase in HHI of 200 in a market with an HHI of 2000 (moderately concentrated), which is a decline of 10 log points, is associated with a decline in wages of about $1.4 \%$. Going from the 25 th percentile of market concentration to the 75 th percentile of market concentration is associated with a decline in wages of $5 \%$ using specification (3), and of $17 \%$ using specification (7), our baseline specification for the IV. ${ }^{6}$

The main threat to identification for the instrumental variable strategy is that productivity shocks to occupations could be correlated across areas. We cannot control for occupation by time fixed effects in the IV specifications due to the fact that the instrument is essentially defined at that level. Nevertheless, it is reassuring to see that controlling for occupation by time effects does not substantively change the OLS results (column 4).

We recognize that the instrument may not be not fully exogenous, and we provide bounds on the second stage effect of $\mathrm{HHI}$ on wages, assuming a degree of endogeneity in the instrument. Using market-level data, we regress wages on the instrument, and controls (Table 4), which gives us the reduced form effect of the instrument. We then calculate the bounds for the second stage effect of $\mathrm{HHI}$ on wages, assuming that the direct effect of the instrument on wages $(\gamma)$ ranges from zero (perfectly exogenous) to the reduced form effect. We use Stata's plausexog and start with a simple specification in column 1, and control for tightness in column 2 . When controlling for tightness, the second stage effect of $\mathrm{HHI}$ on wages ranges between -0.177 and 0.036 (Table 4 , col. $2, \beta$ bounds). The bounds for the second stage estimate exclude zero as long as the direct effect of the instrument is smaller than $-0.112\left(\gamma_{m} a x\right.$ in Table 4 , col. 2$)$, or $75 \%$ of the reduced form effect. Specification 3 adds year-quarter by $\mathrm{CZ}$ fixed effects, and the results

\footnotetext{
${ }^{6}$ The corresponding effects using the 25th and 75th percentiles of the residuals from a regression of log HHI on market and CZ-year-quarter fixed effects are $2 \%$ using specification (3) and $6 \%$ using specification (7).
} 
are very similar to specification 2 . We conclude that the negative impact of concentration on wages is robust to a large degree of instrument endogeneity: the instrument would have to be very endogenous for the impact of concentration on wages to plausibly take positive values.

\subsection{Controlling for job titles}

Marinescu and Wolthoff (2016) showed that job titles are an important predictor of wages

and are informative about the type of job and required skills beyond a pure wage-signalling effect. We are thus interested in studying to what extent market concentration affects wages through job titles and to what extent it has a direct effect beyond the effect that can be explained by job titles. For this purpose, we conducted regressions at the individual vacancy level controlling for job title fixed effects (based on strings capturing the first three words in the vacancy's job title).

The results are shown in Table 3 Panel B. The first three specifications show results using the same controls as in the market-level baseline regressions, and find similar results. The fourth specification controls for commuting-zone times job-title fixed effects. The effect has a negative sign and is statistically significant, but the magnitude is about half of the effect without job title fixed effects. This mitigation of the effect is present in both the OLS and the IV specifications. This indicates that the effect of an increase in market concentration on wages is expressed both directly through lower wages conditional on a job title, as well as by increasing the likelihood of posting lower-wage job titles.

\section{Robustness checks}

\subsection{Interaction with city size}

We tested whether the negative effect of market concentration on wages is driven by small or large cities, or whether it holds across the whole range of city sizes in our sample. For 
this purpose, we ran a specification interacting the vacancy $\mathrm{HHI}$ in a market with a 5th-order polynomial in the percentile of the population of that market's commuting zone, which we instrument using a 5 th-order polynomial in the mean of $\log (1 / N)$ for the same occupation in other CZs.

The estimated effect of market concentration as a function of commuting zone population percentile is shown in Figure 8, together with 95\% confidence bands. The effect is negative and significant over the range of population going from the 10th to the 90th percentile, and it it is higher (in absolute value) for smaller markets than larger markets.

\subsection{Alternative concentration measures}

As a robustness check, we estimated panel IV regressions similar to our baseline specification from Table 3, column 6 , but using $\log 1 / \mathrm{N}$ as the measure of market concentration. The results are similar to the baseline, and shown in Table 5, specification (1).

We also estimated regressions using log $\mathrm{HHI}$ based on share of applications as the measure of concentration, again with similar results. The results are in Table 5, specification (2). This shows that our results are robust to using a range of standard measures of market concentration, and therefore not driven by a particular choice of measure.

\subsection{Alternative market definitions}

We chose to use commuting zones as a market definition because they were designed to capture meaningful geographic labor markets based on commuting patterns across counties. However, the correct geographic definition for labor market competition for hiring is still an open question. We decided to test the sensitivity of our results by using an alternative definition based on counties, and running panel IV specifications analogous to our baseline.

The results are shown in Table 5, specification (3). The estimated coefficient is similar to those in the baseline, indicating that our results are robust to other plausible geographic labor 
market definitions.

\subsection{Excluding monopsony ( $\mathrm{HHI}=1)$ markets}

The histogram in Figure 3 shows that many markets in the sample only have one firm hiring. We checked that our estimates are not sensitive to excluding these markets by running additional regressions that do exactly that. The results from the panel IV specification are reported in Table 5, specification (4), which show that the magnitude and significance of the estimated effect is similar to the analogous specification in the baseline.

\subsection{Cross-sectional specification}

Our baseline specification identifies the effect of market concentration on wages purely from variation within a market over time. One may also be interested in identification from crosssectional variation. We implemented a specification based on the entire 2010-2013 period. We included CZ fixed effects and 6-digit SOC fixed effects, so that our estimates are not driven by variation in average wages across cities, or in average wages across occupations. Similar to the baseline, we instrument the $\log \mathrm{HHI}$ using the $\log 1 / \mathrm{N}$, except that we use the number of firms for the entire period. The impact of concentration on posted wages is still negative and significant in this cross-sectional data (Table 5, specification (5)). Furthermore, we find that the impact of concentration on prevailing wages measured from the BLS occupational employment statistics is also negative and significant (specification (6)). This alleviates the concern that our results are driven by the less than fully representative nature of our data.

\subsection{Controlling for fraction of vacancies posting wages}

An important limitation of the dataset is that only a fraction of the vacancies on CareerBuilder post wages. To address this issue, we ran a panel IV specification controlling for the fraction of vacancies in each market that post wages. Table 5, specification (7) shows the results. 
We find that this variable has a positive effect on wages, but does not meaningfully affect the coefficient on $\log \mathrm{HHI}$.

\subsection{Controlling for tightness based on searches instead of applications}

Another concern is that the tightness measure could be endogenous with respect to wages: high-wage vacancies get more applications, so this lowers the tightness measure. As an alternative measure of tightness, we use the log of the ratio of total vacancies in the market to total searches in the market. Searches should not be affected by posted wages because workers do not search by wage by typically by job title and location, so this can address the endogeneity concern. Table 5, specification (8) shows the results from the corresponding panel IV specification, which are similar to those in the baseline specification.

\subsection{Remaining limitations}

Our analysis accounts for a number of biases in the estimation of the relationship between labor market concentration and posted wages. However, a number of limitations remain.

Only $20 \%$ of vacancies post wages, and we are therefore not measuring all wages in a given occupation by commuting zone market. However, Marinescu and Wolthoff (2016) show that the distribution of posted wages on CareerBuilder is very similar to the distribution of wages for employed workers in the Current Population Survey. Therefore, posted wages are typical of wages overall in the labor market.

Our data comes from a single website, CareerBuilder.com. While this is the largest US website, and contains overall about a third of US vacancies, it does not contain all vacancies in the occupations that are in our sample. This could lead us to overestimate labor market concentration. At the same time, CareerBuilder vacancies are the relevant ones for job seekers that use it as their primary website for job search. Furthermore, the fact that we only capture some of the vacancies should not affect our estimate of the relationship between posted wages 
and labor market concentration.

Our data contains the most frequent occupations by number of vacancies on CareerBuilder.com, and a number of manufacturing occupations. Therefore, our results, while fairly general, do not necessarily apply to the whole US labor market. It is noteworthy that Benmelech, Bergman and Kim (2018) and Rinz (2018) find a negative and significant relationship between wages and employment concentration at the county and industry level. Therefore, studying employment rather than vacancies and changing the labor market definition does not affect the basic fact that wages are negatively associated with labor market concentration.

\section{Discussion and conclusion}

Labor economists are increasingly questioning the assumption of almost-perfectly-competitive labor markets (Card et al., 2016), and they have begun to address the antitrust policy implications of relaxing that assumption. Ashenfelter and Krueger (2017) study the prevalence of anti-competitive no-poaching language in franchising contracts, leading to a series of recent antitrust cases against franchise employers. Marinescu and Hovenkamp (2018) and Naidu, Posner and Weyl (2018) both consider the implications of concentrated labor markets for merger enforcement. Recently, the chairman of the FTC said in Congressional testimony that he had instructed the agency's staff to examine the labor market impact of every merger the agency reviews, and he further elaborated that market definition in labor markets for antitrust enforcement purposes should be guided by the elasticity of labor supply to the individual firm (Simons, 2018).

The idea that monopsony power can harm efficiency dates to the origins of American antitrust policy. One of the reasons Senator John Sherman gave for legislating against monopoly was that "[i]t commands the price of labor without fear of strikes, for in its field it allows no competitors." (Congressional Record 2457, 1890) The horizontal merger guidelines recognize that the same framework can be applied to market power on the part of buyers as well as sell- 
ers, although there have been few merger challenges premised on monopsony theories of harm, and none in which the labor market is where the monopsony power is being challenged ${ }^{7}$.

In this paper, we contribute to this growing debate by calculating measures of market concentration in local labor markets for the most frequent occupations on the leading employment website CareerBuilder.com. We have shown that concentration is high, and increasing concentration is associated with lower wages. Our results suggest that the anti-competitive effects of concentration on the labor market could be important. The type of analysis we provide could be used to incorporate labor market concentration concerns as a factor in antitrust analysis.

\footnotetext{
${ }^{7}$ Antitrust agencies have recently brought to court conduct cases regarding labor market monopsony in which they found evidence of overt written agreements not to compete for workers (DOJ, 2007, 2010).
} 


\section{References}

Artuc, Erhan, and John McLaren. 2015. "Trade policy and wage inequality: A structural analysis with occupational and sectoral mobility." Journal of International Economics, 97: 28-41.

Artuc, Erhan, Shubham Chaudhuri, and John McLaren. 2010. "Trade Shocks and Labor Adjustment: A Structural Empirical Approach." American Economic Review, 100: 1008-1045.

Ashenfelter, Orley, and Alan B. Krueger. 2017. “Theory and Evidence on Employer Collusion in the Franchise Sector." Princeton University Industrial Relations Section Working Paper. DOI: $10.3386 /$ w23396.

Ashenfelter, Orley C., Henry Farber, and Michael R. Ransom. 2010. “Labor market monopsony." Journal of Labor Economics, 28(2): 203-210.

Autor, David, David Dorn, Lawrence F. Katz, Christina Patterson, and John Van Reenen. 2017. "The Fall of the Labor Share and the Rise of Superstar Firms." National Bureau of Economic Research Working Paper 23396. DOI: 10.3386/w23396.

Autor, David H., David Dorn, and Gordon H. Hanson. 2013. “The China Syndrome: Local Labor Market Effects of Import Competition in the United States." American Economic Review, 103(6): 2121-2168.

Barkai, Simcha. 2016. “Declining Labor and Capital Shares."

Bartik, Alexander W. 2018. "Moving Costs and Worker Adjustment to Changes in Labor Demand: Evidence from Longitudinal Census Data."

Baum-Snow, Nathaniel, and Ronni Pavan. 2012. "Understanding the City Size Wage Gap." The Review of Economic Studies, 79(1): 88-127.

Benmelech, Efraim, Nittai Bergman, and Hyunseob Kim. 2018. "Strong Employers and Weak Employees: How Does Employer Concentration Affect Wages?" 
BLS. 2017. “Unemployed persons by duration of unemployment.” Bureau of Labor Statistics.

Boal, William M., and Michael R Ransom. 1997. "Monopsony in the Labor Market." Journal of Economic Literature, 35(1): 86-112.

Bunting, Robert. 1962. Employer Concentration in Local Labor Markets. University of North Carolina Press.

Card, David, Ana Rute Cardoso, Joerg Heining, and Patrick Kline. 2016. “Firms and Labor Market Inequality: Evidence and Some Theory."

CEA. 2016. "Labor market monopsony: trends, consequences, and policy responses." White House Council of Economics Adivsors.

Clarke, Damian. 2017. "PLAUSEXOG: Stata module to implement Conley et al's plausibly exogenous bounds."

Conley, Timothy G., Christian B. Hansen, and Peter E. Rossi. 2010. "Plausibly Exogenous." The Review of Economics and Statistics, 94(1): 260-272.

Davis, Steven J., and Ioana E. Marinescu. 2017. "Posted wages and labor market conditions." working paper.

De Loecker, Jan, and Jan Eeckhout. 2017. “The Rise of Market Power and the Macroeconomic Implications."

Dix-Caneiro, Rafael. 2014. "Trade Liberalization and Labor Market Dynamics." Econometrica, 82: 825-885.

DOJ. 2007. “United States v. Arizona Hospital and Healthcare Association.” Complaint.

DOJ. 2010. “United States v. Adobe Systems, Inc. et al.” Complaint.

Dube, Arindrajit, Jeff Jacobs, Suresh Naidu, and Siddharth Suri. 2019. "Monopsony in Online Labor Markets." American Economic Review: Insights. 
Falch, Torberg. 2010. "The Elasticity of Labor Supply at the Establishment Level." Journal of Labor Economics, 28(2): 237-266.

FTC/DOJ. 2010. “Horizontal merger guidelines." FTC/DOJ Washington DC.

Hershbein, Brad, and Lisa B. Kahn. 2016. “Do Recessions Accelerate Routine-Biased Technological Change? Evidence from Vacancy Postings." National Bureau of Economic Research Working Paper 22762. DOI: 10.3386/w22762.

Hyatt, Henry R., and James R. Spletzer. 2016. “The Shifting Job Tenure Distribution." Labour Economics, 41: 363-377.

Macaluso, Claudia. 2017. “Skill remoteness and post-layoff labor market outcomes."

Manning, Alan. 2010. “The plant size-place effect: agglomeration and monopsony in labour markets." Journal of Economic Geography, 10(5): 717-744.

Manning, Alan. 2011. "Imperfect competition in the labor market." Handbook of labor economics, 4: 973-1041.

Manning, Alan, and Barbara Petrongolo. 2017. “How Local Are Labor Markets? Evidence from a Spatial Job Search Model." American Economic Review, 107(10): 2877-2907.

Marinescu, Ioana, and Herbert J. Hovenkamp. 2018. "Anticompetitive Mergers in Labor Markets." Faculty Scholarship at Penn Law.

Marinescu, Ioana, and Roland Rathelot. 2018. "Mismatch Unemployment and the Geography of Job Search." American Economic Journal: Macroeconomics, 10(3): 42-70.

Marinescu, Ioana, and Ronald Wolthoff. 2016. "Opening the Black Box of the Matching Function: the Power of Words." National Bureau of Economic Research Working Paper 22508. DOI: $10.3386 / w 22508$. 
Matsudaira, Jordan D. 2013. "Monopsony in the Low-Wage Labor Market? Evidence from Minimum Nurse Staffing Regulations." The Review of Economics and Statistics, 96(1): 92-102.

Modestino, Alicia Sasser, Daniel Shoag, and Joshua Ballance. 2016. "Downskilling: Changes in Employer Skill Requirements Over the Business Cycle."

Naidu, Suresh, Eric A. Posner, and E. Glen Weyl. 2018. "Antritrust Remedies for Labor Market Power." Harvard Law Review.

Nevo, Aviv. 2001. "Measuring market power in the ready-to-eat cereal industry." Econometrica, 69(2): 307-342.

Ransom, Michael R, and David P. Sims. 2010. "Estimating the Firm's Labor Supply Curve in a "New Monopsony" Framework: Schoolteachers in Missouri." Journal of Labor Economics, 28(2): 331-355.

Rinz, Kevin. 2018. “Labor Market Concentration, Earnings Inequality, and Earnings Mobility." Center for Economic Studies, US Census Bureau Working Paper 2018-10.

Rogerson, Richard, Robert Shimer, and Randall Wright. 2005. "Search-Theoretic Models of the Labor Market: A Survey." Journal of Economic Literature, 43(4): 959-988. ArticleType: research-article / Full publication date: Dec., 2005 / Copyright (C) 2005 American Economic Association.

Simons, Joseph. 2018. "Oversight of the Enforcement of the Antitrust Laws." Senate Judiciary Committee Congressional Hearing.

Staiger, Douglas O, Joanne Spetz, and Ciaran S Phibbs. 2010. "Is there monopsony in the labor market? Evidence from a natural experiment." Journal of Labor Economics, 28(2): 211236.

Traiberman, Sharon. 2017. "Occupations and Import Competition: Evidence from Denmark." 
Webber, Douglas A. 2015. "Firm market power and the earnings distribution." Labour Economics, 35: 123-134.

Yankow, Jeffrey J. 2006. "Why do cities pay more? An empirical examination of some competing theories of the urban wage premium." Journal of Urban Economics, 60(2): 139-161. 
Table 1. Summary statistics. This table shows summary statistics for our sample consisting of commuting zoneoccupational code (6-digit SOC) labor markets over the period 2010Q1-2013Q4.

\begin{tabular}{lccccc}
\hline \hline & Mean & Std. Dev. & Min & Max & Obs. \\
\hline Real Wage & & & & & \\
Vacancies & 41547.36 & 36216.76 & 4.71 & 5504385 & 61017 \\
Applications & 82.95 & 224.39 & 1 & 17928 & 61017 \\
Searches & 3612.96 & 14416.02 & 0 & 528289 & 61017 \\
Log Tightness & 441156.09 & 1385720.05 & 0 & 78808601 & 61017 \\
Number of Firms & -2.9 & 1.36 & -7.64 & 4.48 & 60200 \\
& 20.03 & 35.78 & 1 & 571 & 61017 \\
HHI (Vacancies, CZ Quarterly) - Baseline & & & & & \\
HHI (Applications, CZ Quarterly) & 3157.02 & 2923.92 & 66.04 & 10000 & 61017 \\
& 3480.17 & 3061.03 & 0 & 10000 & 61017 \\
HHI (Vacancies, CZ Monthly) & & & & & \\
HHI (Vacancies, CZ Semesterly) & 3251.69 & 3004.4 & 74.23 & 10000 & 132461 \\
HHI (Vacancies, CZ Yearly) & 3090.29 & 2872.86 & 58.57 & 10000 & 38503 \\
HHI (Vacancies, CZ Whole Period) & 2970.47 & 2780.11 & 51.91 & 10000 & 24060 \\
& 2541.6 & 2498.51 & 54.76 & 10000 & 8979 \\
HHI (Applications, CZ Monthly) & & & & & \\
HHI (Applications, CZ Semesterly) & 3790.37 & 3132.18 & 0 & 10000 & 132461 \\
HHI (Applications, CZ Yearly) & 3315.38 & 3017.08 & 0 & 10000 & 38503 \\
HHI (Applications, CZ Whole Period) & 3120 & 2900.47 & 0 & 10000 & 24060 \\
& 2722.97 & 2653.19 & 0 & 10000 & 8979 \\
HHI (Vacancies, CZ Quarterly, Population-Weighted) & 1690.74 & 1942.09 & 66.04 & 10000 & 61013 \\
HHI (Applications, CZ Quarterly, Population-Weighted) & 1848.51 & 2127.09 & 0 & 10000 & 61013 \\
& & & & & \\
HHI (Vacancies, County Quarterly) & 4222.52 & 3331.36 & 76.09 & 10000 & 111109 \\
HHI (Applications, County Quarterly) & 4563.85 & 3369.67 & 0 & 10000 & 111109 \\
HHI (Vacancies, State Quarterly) & 1358.48 & 1634.58 & 64.01 & 10000 & 15124 \\
HHI (Applications, State Quarterly) & 1458.09 & 1781.24 & 0 & 10000 & 15124 \\
\hline \hline
\end{tabular}


Table 2. Effect of Market Concentration on Real Wages: Panel Regressions (First Stage). Data are for the period 2010Q1-2013Q4. We cluster standard errors at the market level.

Panel A: Market-level regressions

\begin{tabular}{lccc}
\hline \hline & \multicolumn{3}{c}{ Dependent Variable: Log HHI (Vacancies) } \\
\cline { 2 - 4 } & \multicolumn{1}{c}{$(1)$} & $(2)$ & $(3)$ \\
\hline & & & \\
Average Log $(1 / \mathrm{N})$ in Other Markets & $1.005^{* * *}$ & $1.046^{* * *}$ & $1.074^{* * *}$ \\
& $(0.0344)$ & $(0.0323)$ & $(0.0340)$ \\
Log Tightness & & $0.171^{* * *}$ & $0.198^{* * *}$ \\
& & $(0.00471)$ & $(0.00558)$ \\
Market (CZ $\times$ 6-digit SOC) FE & $\checkmark$ & $\checkmark$ & $\checkmark$ \\
Year-quarter FE & $\checkmark$ & $\checkmark$ & $\checkmark$ \\
Year-quarter FE $\times$ CZ FE & & & \\
Observations & & & 56,679 \\
R-squared & 59,485 & 58,642 & 0.865 \\
\hline \hline
\end{tabular}

Panel B: Vacancy-level regressions

Dependent Variable: Log HHI (Vacancies)

(1)

(2)

(3)

$(4)$

\begin{tabular}{|c|c|c|c|c|}
\hline Average Log $(1 / N)$ in Other Markets & $\begin{array}{c}0.871^{* * *} \\
(0.129)\end{array}$ & $\begin{array}{c}0.926^{* * *} \\
(0.124)\end{array}$ & $\begin{array}{c}0.889^{* * *} \\
(0.116)\end{array}$ & $\begin{array}{l}0.931^{* * *} \\
(0.0760)\end{array}$ \\
\hline Log Tightness & & $\begin{array}{l}0.341^{* * *} \\
(0.0162)\end{array}$ & $\begin{array}{l}0.451^{* * *} \\
(0.0186)\end{array}$ & $\begin{array}{l}0.252^{* * *} \\
(0.0146)\end{array}$ \\
\hline $\begin{array}{l}\mathrm{CZ} \times \text { 6-digit SOC FE } \\
\text { Year-quarter FE } \\
\text { Year-quarter FE } \times \text { CZ FE } \\
\mathrm{CZ} \times \text { Job-Title FE }\end{array}$ & $\begin{array}{l}\checkmark \\
\checkmark\end{array}$ & $\begin{array}{l}\checkmark \\
\checkmark\end{array}$ & $\begin{array}{l}\checkmark \\
\checkmark\end{array}$ & $\begin{array}{l}\checkmark \\
\checkmark\end{array}$ \\
\hline $\begin{array}{l}\text { Observations } \\
\text { R-squared }\end{array}$ & $\begin{array}{c}1,023,295 \\
0.902\end{array}$ & $\begin{array}{c}1,021,185 \\
0.913\end{array}$ & $\begin{array}{c}1,020,510 \\
0.928\end{array}$ & $\begin{array}{c}955,641 \\
0.948\end{array}$ \\
\hline
\end{tabular}


Table 3. Effect of Market Concentration on Real Wages: Panel Regressions.

Data are for the period 2010Q1-2013Q4. We cluster standard errors at the market level.

Panel A: Market-level regressions

\begin{tabular}{|c|c|c|c|c|c|c|c|c|}
\hline & \multicolumn{8}{|c|}{ Dependent Variable: Log( Real Wage) } \\
\hline & (1) & $(2)$ & (3) & (4) & (5) & (6) & (7) & (8) \\
\hline Log HHI (Vacancies) & $\begin{array}{l}-0.103^{* * *} \\
(0.00456)\end{array}$ & $\begin{array}{c}-0.0347^{* * *} \\
(0.00377)\end{array}$ & $\begin{array}{c}-0.0399^{* * *} \\
(0.00392)\end{array}$ & $\begin{array}{c}-0.0378^{* * *} \\
(0.00406)\end{array}$ & $\begin{array}{l}-0.0300^{* * *} \\
(0.00422)\end{array}$ & $\begin{array}{c}-0.141^{* * *} \\
(0.0191)\end{array}$ & $\begin{array}{c}-0.143^{* * *} \\
(0.0181)\end{array}$ & $\begin{array}{c}-0.127^{* * *} \\
(0.0176)\end{array}$ \\
\hline Log Tightness & & & $\begin{array}{l}0.0113^{* * *} \\
(0.00320)\end{array}$ & $\begin{array}{l}0.0132^{* * *} \\
(0.00357)\end{array}$ & $\begin{array}{c}0.00686^{*} \\
(0.00360)\end{array}$ & & $\begin{array}{l}0.0283^{* * *} \\
(0.00427)\end{array}$ & $\begin{array}{l}0.0305^{* * *} \\
(0.00479)\end{array}$ \\
\hline Year-quarter FE & $\checkmark$ & $\checkmark$ & $\checkmark$ & & & $\checkmark$ & $\checkmark$ & \\
\hline Market $(\mathrm{CZ} \times 6$-digit SOC) FE & & $\checkmark$ & $\checkmark$ & $\checkmark$ & $\checkmark$ & $\checkmark$ & $\checkmark$ & $\checkmark$ \\
\hline Year-quarter FE $\times \mathrm{CZ}$ FE & & & & $\checkmark$ & $\checkmark$ & & & $\checkmark$ \\
\hline Year-quarter FE $\times$ 6-digit SOC FE & & & & & $\checkmark$ & & & \\
\hline Observations & 61,017 & 59,485 & 58,642 & 56,679 & 56,677 & 59,485 & 58,642 & 56,679 \\
\hline R-squared & 0.042 & 0.674 & 0.672 & 0.715 & 0.738 & -0.018 & -0.015 & -0.012 \\
\hline Kleibergen-Paap F-stat & & & & & & 854.3 & 1051 & 996.7 \\
\hline
\end{tabular}

Panel B: Vacancy-level regressions

\begin{tabular}{|c|c|c|c|c|c|c|c|c|}
\hline & \multicolumn{8}{|c|}{ Dependent Variable: Log( Real Wage) } \\
\hline & \multicolumn{4}{|c|}{ OLS } & \multicolumn{4}{|c|}{ IV } \\
\hline & (1) & $(2)$ & (3) & (4) & (5) & (6) & (7) & $(8)$ \\
\hline Log HHI (Vacancies) & $\begin{array}{c}-0.0327^{* * *} \\
(0.00453)\end{array}$ & $\begin{array}{c}-0.0331^{* * *} \\
(0.00476)\end{array}$ & $\begin{array}{c}-0.0314^{* * *} \\
(0.00500)\end{array}$ & $\begin{array}{c}-0.0154^{* * *} \\
(0.00377)\end{array}$ & $\begin{array}{c}-0.200^{* * *} \\
(0.0398)\end{array}$ & $\begin{array}{c}-0.192^{* * *} \\
(0.0361)\end{array}$ & $\begin{array}{c}-0.188^{* * *} \\
(0.0370)\end{array}$ & $\begin{array}{c}-0.116^{* * *} \\
(0.0184)\end{array}$ \\
\hline Log Tightness & & $\begin{array}{l}0.000665 \\
(0.00342)\end{array}$ & $\begin{array}{c}0.00429 \\
(0.00462)\end{array}$ & $\begin{array}{c}0.00818^{* * *} \\
(0.00297)\end{array}$ & & $\begin{array}{c}0.0540^{* * *} \\
(0.0133)\end{array}$ & $\begin{array}{c}0.0737^{* * *} \\
(0.0180)\end{array}$ & $\begin{array}{l}0.0315^{* * *} \\
(0.00601)\end{array}$ \\
\hline $\mathrm{CZ} \times$ 6-digit SOC FE & $\checkmark$ & $\checkmark$ & $\checkmark$ & & $\checkmark$ & $\checkmark$ & $\checkmark$ & \\
\hline Year-quarter FE & $\checkmark$ & $\checkmark$ & & $\checkmark$ & $\checkmark$ & $\checkmark$ & & $\checkmark$ \\
\hline Year-quarter FE $\times \mathrm{CZ}$ FE & & & $\checkmark$ & & & & $\checkmark$ & \\
\hline $\mathrm{CZ} \times$ Job-Title FE & & & & $\checkmark$ & & & & $\checkmark$ \\
\hline Observations & $1,023,295$ & $1,021,185$ & $1,020,510$ & 955,641 & $1,023,295$ & $1,021,185$ & $1,020,510$ & 955,641 \\
\hline R-squared & 0.533 & 0.533 & 0.541 & 0.849 & 0.522 & 0.524 & 0.534 & 0.847 \\
\hline Kleibergen-Paap F-stat & & & & & 45.62 & 56.18 & 58.72 & 150.1 \\
\hline
\end{tabular}


Table 4. Plausibly Exogenous Instrument Regressions (Market-level data).

Data are for the period 2010Q1-2013Q4. We consider the following model, in which the instrument is not fully exogenous and therefore can enter in the second stage:

$$
\log \left(w_{m, t}\right)=\beta \cdot \log \mathrm{HHI}_{m, t}+\gamma \cdot z+\theta \cdot X_{m, t}+\alpha_{t}+v_{m}+\varepsilon_{m, t}
$$

where $z$ is our instrumental variable. We implement the plausibly exogenous instrument regression methodology as follows. We start by running reduced form OLS regressions analogous to our IV specifications, but including the instrument directly in the second stage instead of $\log$ HHI. The value of $\hat{\gamma}$ in the table refers to the coefficient of the instrument in this regression. We take $\hat{\gamma}$ as the lower bound for the range of $\gamma$, and zero as the upper bound, and then compute bounds for the coefficient on $\log H H I(\beta)$ using the plausibly exogenous regression methodology of Conley, Hansen and Rossi (2010). We implement the methodology by (i) within-transforming all the variables (including the dependent variable, the regressors, and the instruments) by running regressions with each variable on the left hand side and the corresponding set of fixed effects on the right hand side, and taking the residuals as the transformed variables, and (ii) running the plausibly exogenous instrument regressions on the within-transformed variables using the plausexog command in Stata developed by Clarke (2017). We cluster standard errors at the market level. We also calculate the value of the lower bound for $\gamma$ that would make the interval for $\beta$ be fully to the left of zero. We call this value $\gamma_{\max }$.

\begin{tabular}{|c|c|c|c|}
\hline & Depende & it Variable: & (Real Wage) \\
\hline & (1) & (2) & (3) \\
\hline$\hat{\gamma}$ & $-0.141^{* * *}$ & $-0.149^{* * *}$ & $-0.137^{* * *}$ \\
\hline & $(0.0186)$ & $(0.0184)$ & $(0.0184)$ \\
\hline Log Tightness & & 0.00387 & 0.00526 \\
\hline & & $(0.00310)$ & $(0.00344)$ \\
\hline Market $(\mathrm{CZ} \times$ 6-digit SOC) FE & $\checkmark$ & $\checkmark$ & $\checkmark$ \\
\hline Year-quarter FE & $\checkmark$ & $\checkmark$ & \\
\hline Year-quarter $\mathrm{FE} \times \mathrm{CZ}$ FE & & & $\checkmark$ \\
\hline Observations & 59,485 & 58,642 & 56,679 \\
\hline R-squared & 0.674 & 0.671 & 0.715 \\
\hline$\beta$ (Lower Bound) & -0.178 & -0.177 & -0.157 \\
\hline$\beta$ (Upper Bound) & 0.0362 & 0.0357 & 0.0349 \\
\hline$\gamma_{\max }$ & -.105 & -.112 & -.100 \\
\hline
\end{tabular}


Table 5. Effect of Market Concentration on Real Wages: Robustness Checks (Panel IV).

Data are for the period 2010Q1-2013Q4. We cluster standard errors at the market level. In all cases, we report results from a panel IV specification using the average of $\log (1 / \mathrm{N})$ for the same 6-digit SOC occupation in other commuting zones.

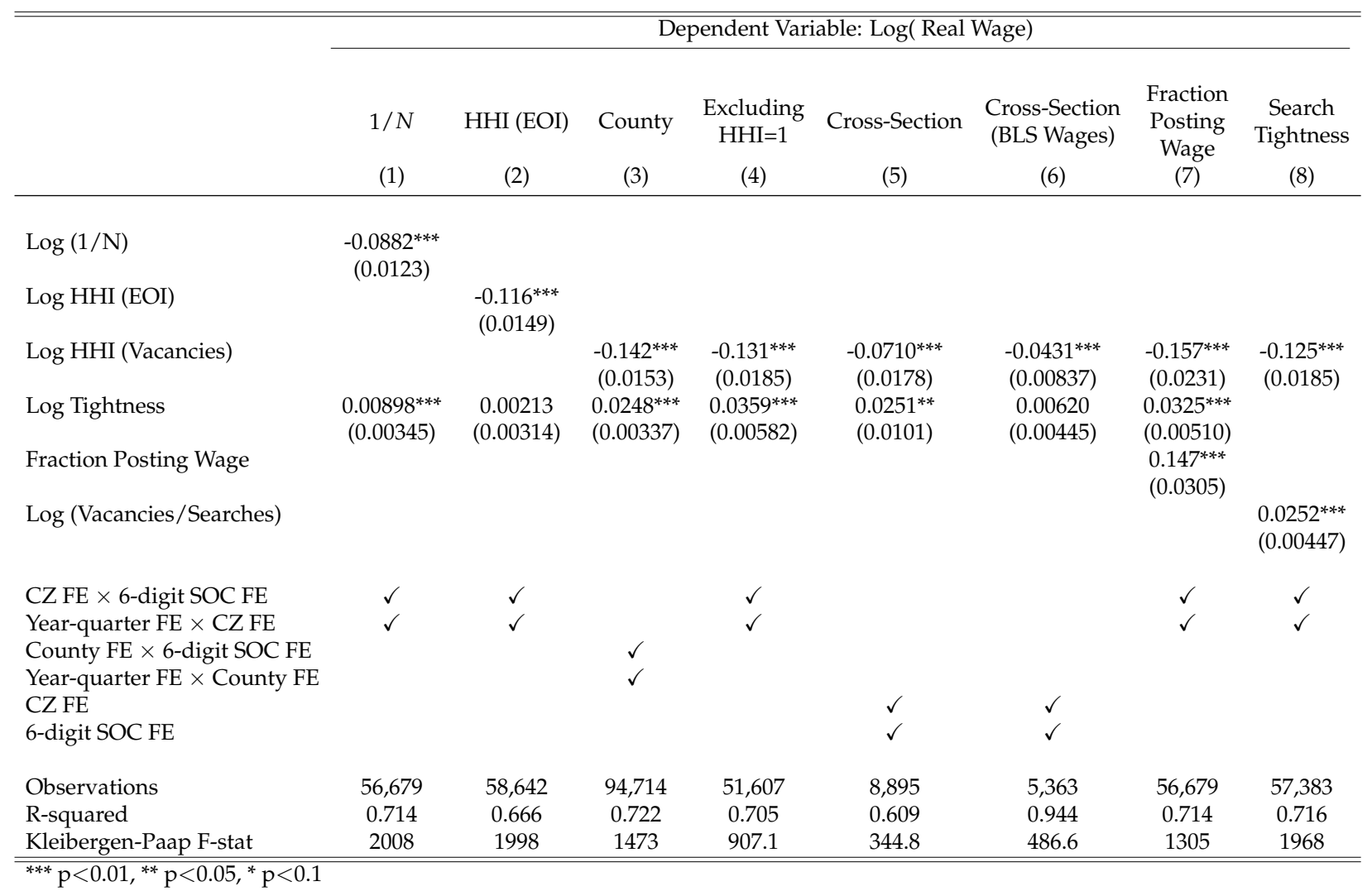




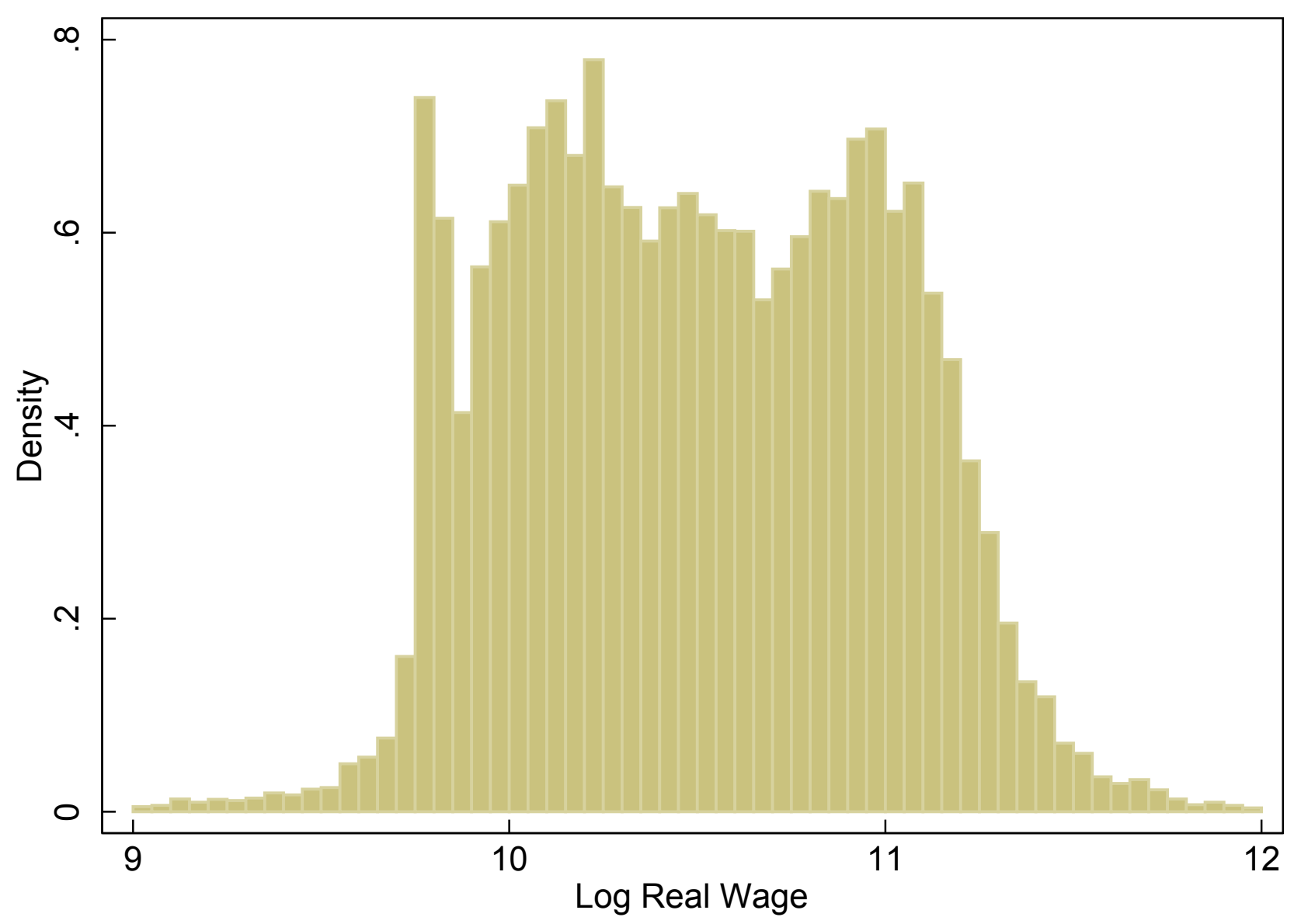

Figure 1. Histogram of log real wages across markets. This figure shows a histogram of the log real wage for labor markets over the period 2010Q1-2013Q4. The real wage is defined as the average wage across wage-posting vacancies in a given market and year-quarter, divided by the consumer price index for that year-quarter. 


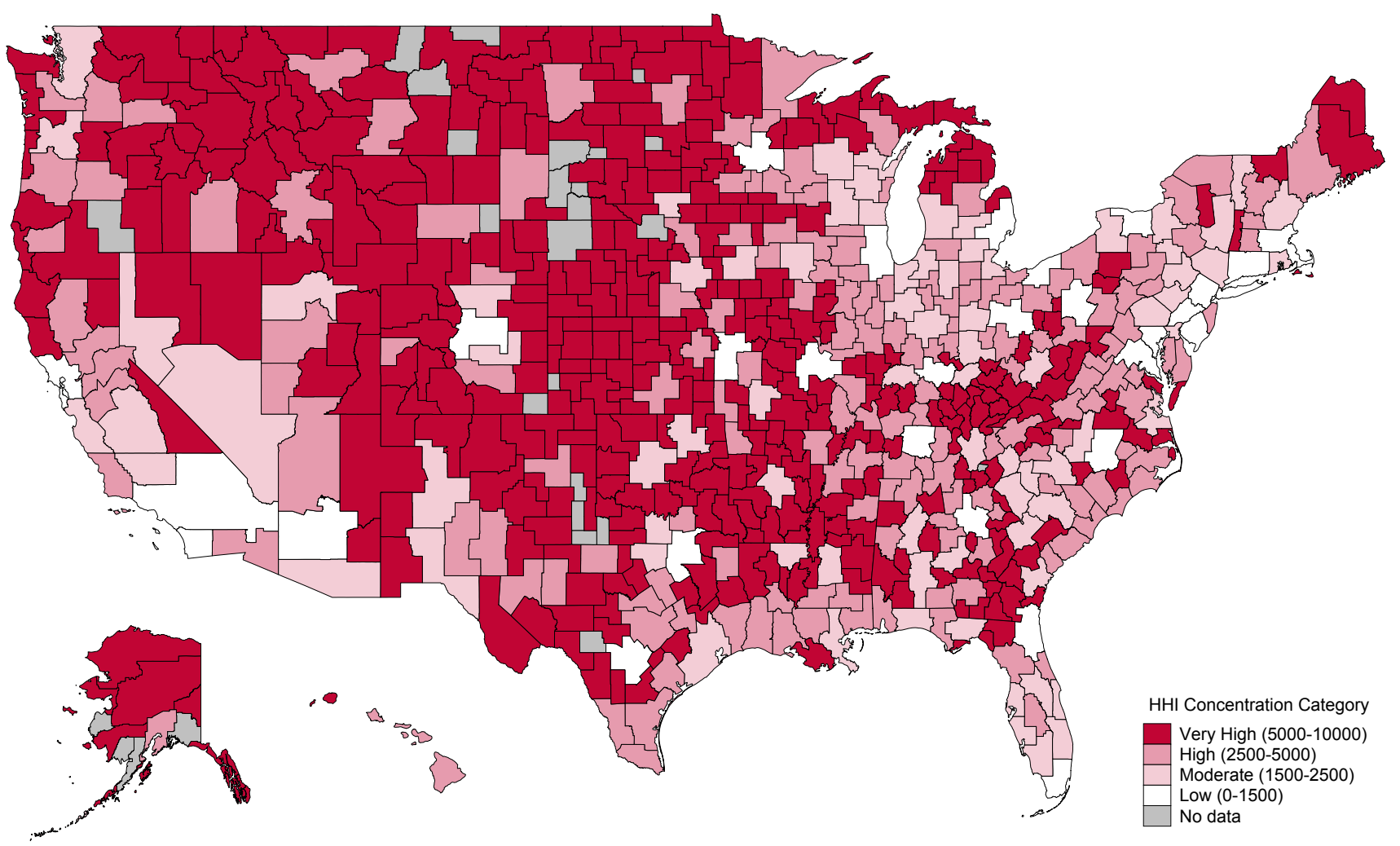

Figure 2. Average HHI by commuting zone, based on vacancy shares. This figure shows the average of the Herfindahl-Hirschman Index by 6-digit SOC occupation code for labor markets over the period 2010Q1-2013Q4. The categories we use for HHI concentration levels are: "Low": HHI between 0 and 1500; "Moderate": HHI between 1500 and 2500; "High": HHI between 2500 and 5000; "Very High": HHI between 5000 and 10000. These categories correspond to the DOJ/FTC guidelines, except that we add the additional distinction between high and very high concentration levels around the 5,000 $\mathrm{HHI}$ threshold. Market shares are defined as the sum of vacancies posted in CareerBuilder.com by a given firm in a given market and year-quarter divided by total vacancies posted in the website in that market and year-quarter. 


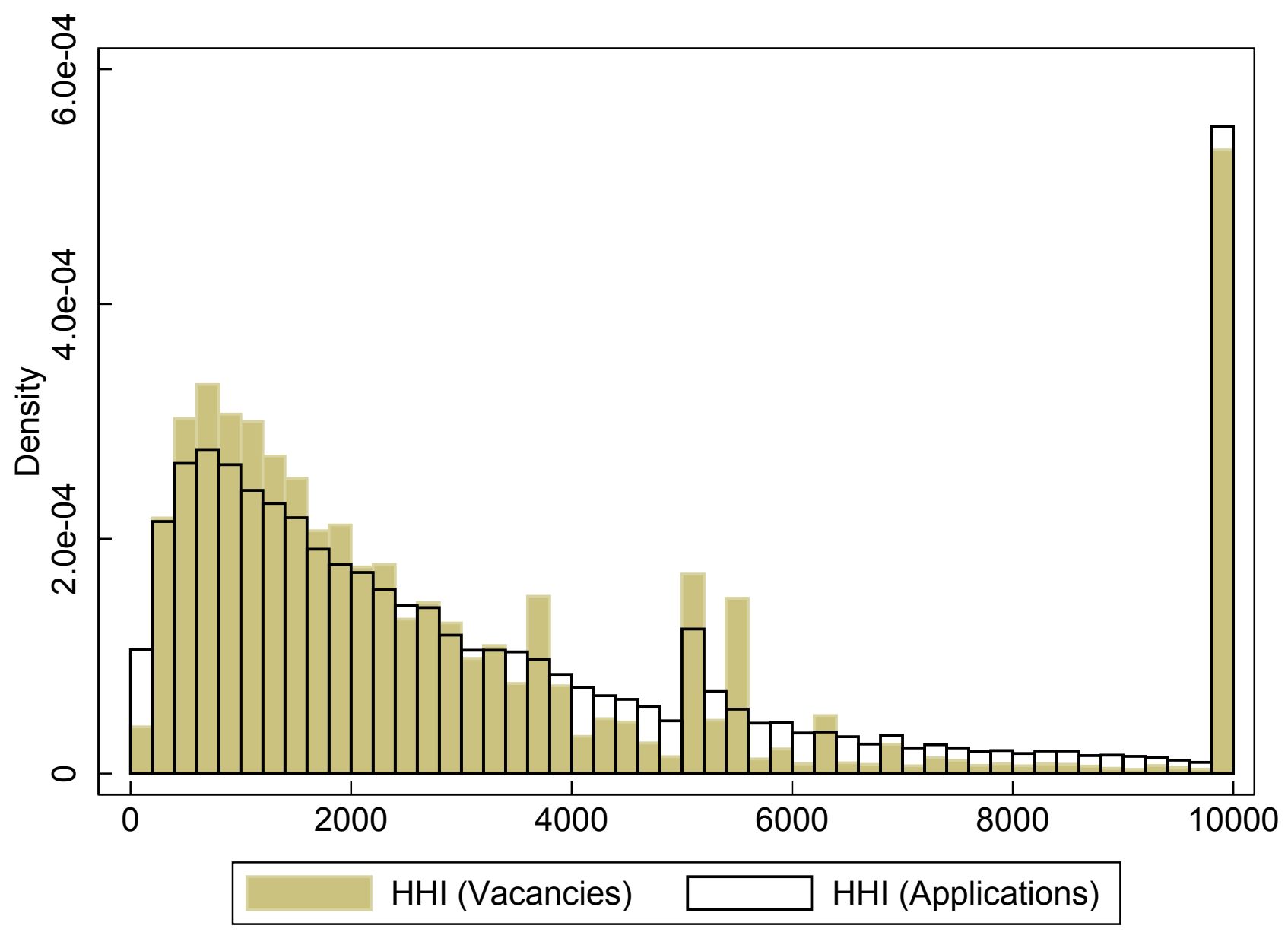

Figure 3. Histogram of HHIs based on application shares and vacancy shares. This figure shows a histogram of the Herfindahl-Hirschman Index for labor markets over the period 2010Q1-2013Q4. Market shares are defined as either the sum of vacancies posted in CareerBuilder.com by a given firm in a given market and year-quarter divided by total vacancies posted in the website in that market and year-quarter, or as the sum of applications (EOI) through the website to a given firm in a given market and year-quarter divided by the total number of applications to all firms in that market and year-quarter. 




Figure 4. Average HHI by occupation, based vacancy shares. This figure shows the average of the HerfindahlHirschman Index by 6-digit SOC occupation code for labor markets over the period 2010Q1-2013Q4. Market shares are defined as the sum of vacancies posted in CareerBuilder.com by a given firm in a given market and year-quarter divided by total vacancies posted in the website in that market and year-quarter. 


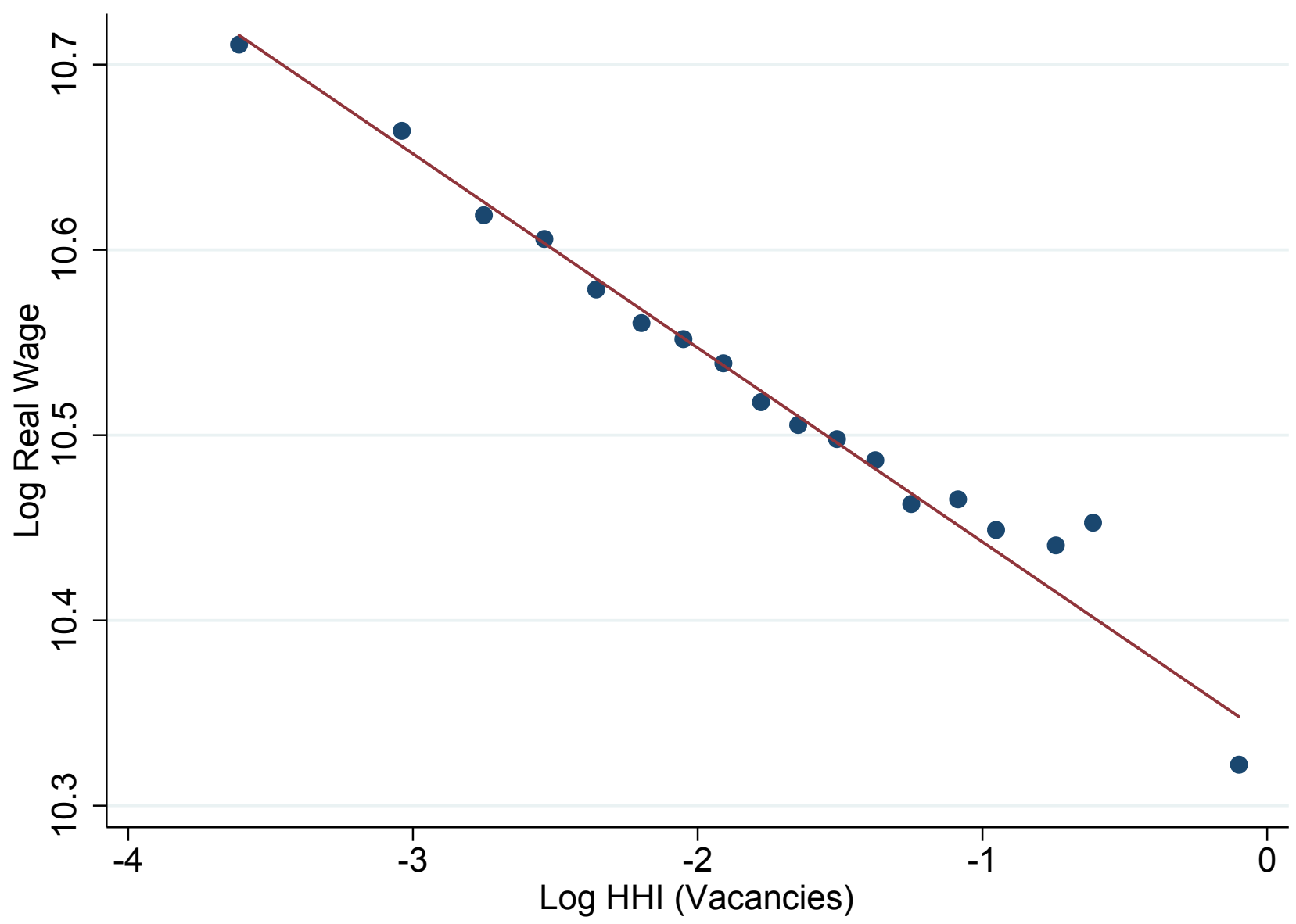

Figure 5. Binned scatter of log HHI based on vacancies and log real wage. This figure shows a binned scatter plot of $\log \mathrm{HHI}$ based on vacancy shares and log real wage in the same market, using 18 quantiles. 


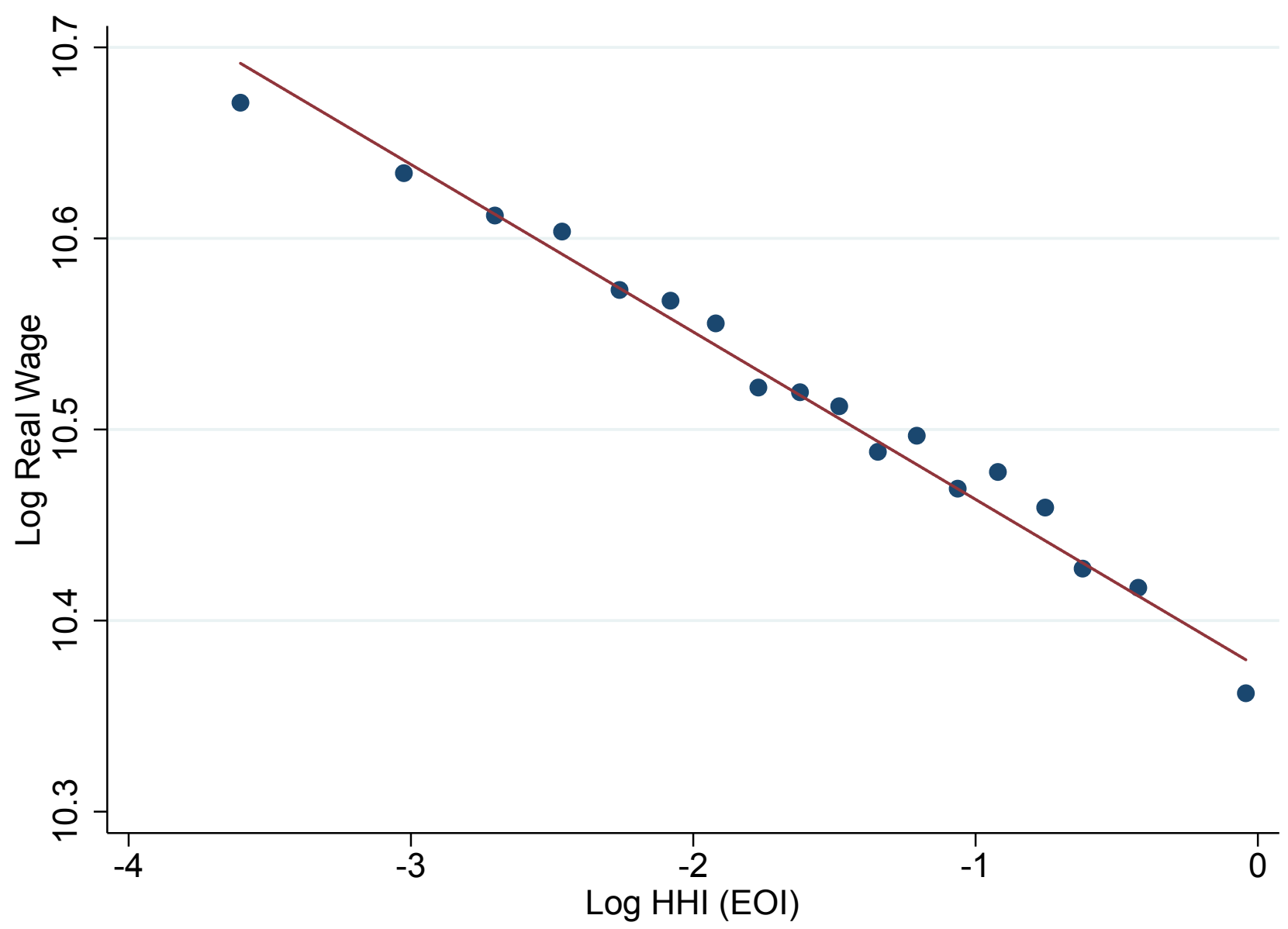

Figure 6. Binned scatter of $\log$ HHI based on applications and $\log$ real wage. This figure shows a binned scatter plot of $\log$ HHI based on application shares and log real wage in the same market, using 18 quantiles. 


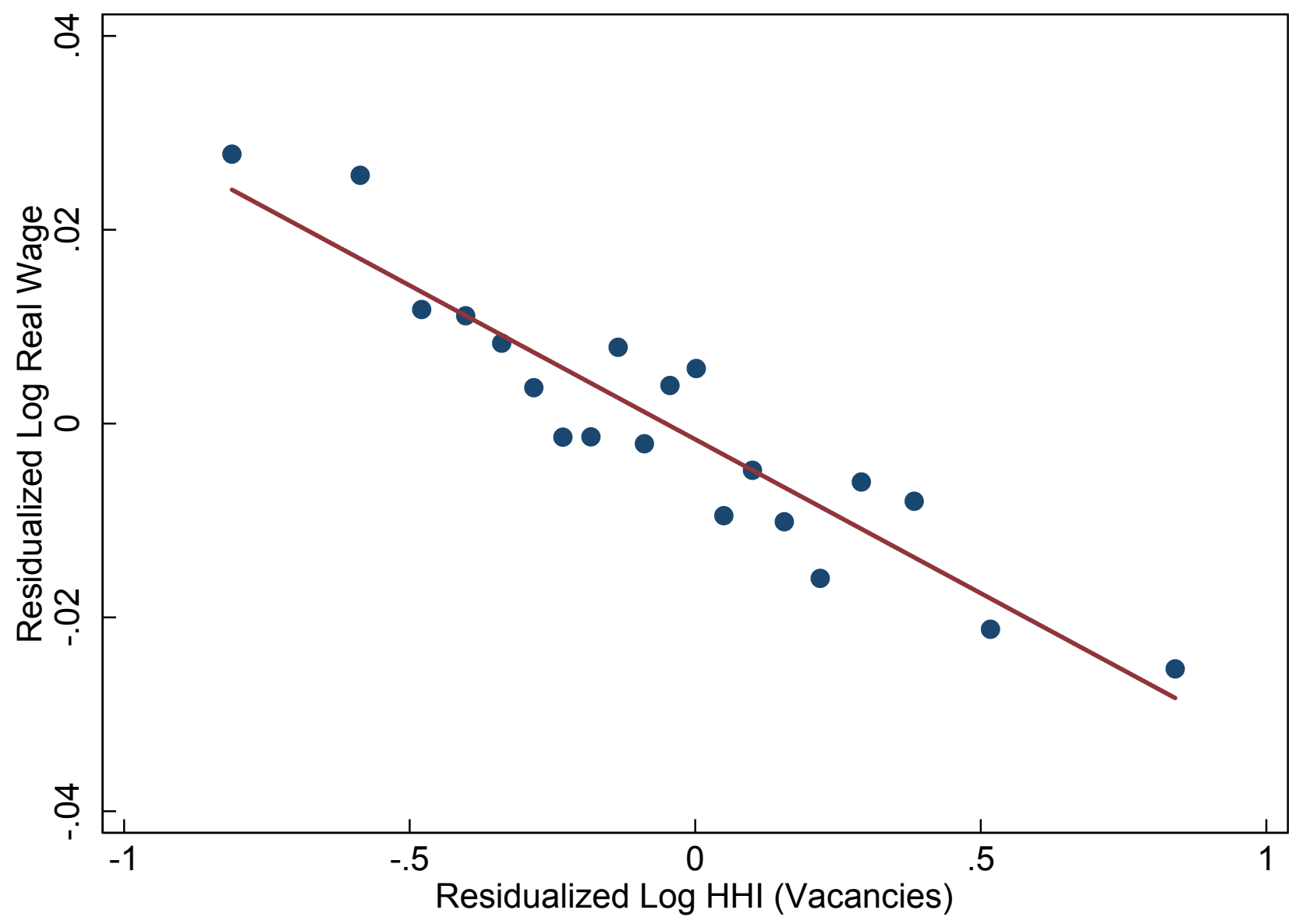

Figure 7. Binned scatter of residualized log HHI based on vacancies and residualized log real wage. This figure shows a binned scatter plot of the residuals of a regression of log HHI (based on vacancy shares) on log tightness, CZ times SOC fixed effects, and CZ times year-quarter fixed effects and the residuals of a regression of log real wage in the same market, also on log tightness, CZ times SOC fixed effects, and CZ times year-quarter fixed effects. 


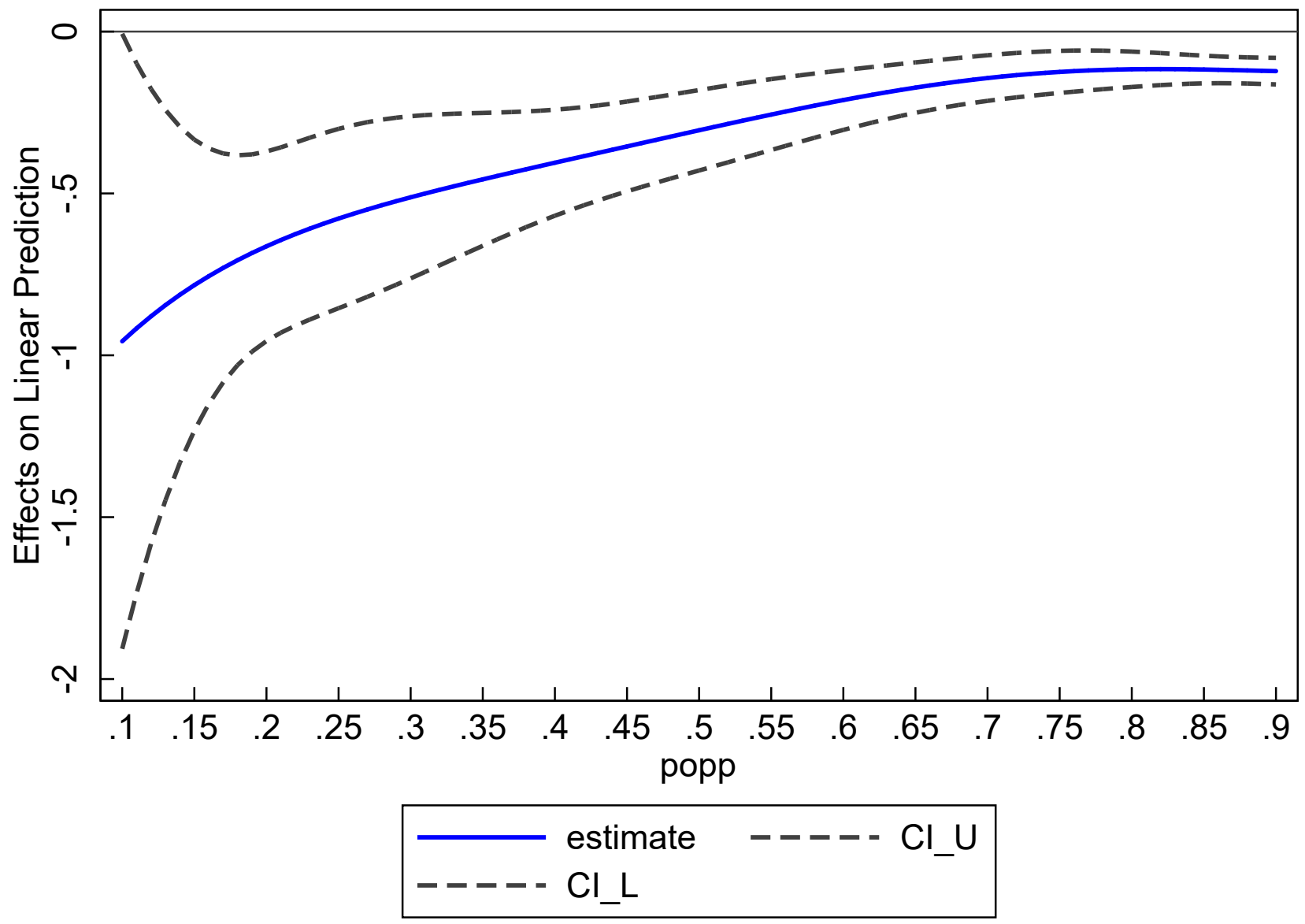

Figure 8. Effect of Log HHI (Vacancies) on Log Real Wage by Commuting Zone Population Percentile. Estimated effect from a panel IV regression of log real wage on a 5th order polynomial in log HHI (in terms of vacancies), instrumented with a 5 th order polynomial in average $\log 1 / \mathrm{N}$ in other commuting zones for the same occupation, controlling for log tightness, CZ-6-digit SOC fixed effects and time fixed effects. Data are for the period 2010Q1-2013Q4. We cluster standard errors at the market level. 